PhD in Pedagogical Sciences, Associate Professor, MYKOLA KURACH National Pedagogical Dragomanov University, Ukraine Address: 9 Pyrohova St., Kyiv, 01601, Ukraine E-mail: kurachnick@meta.ua

\title{
THE DEVELOPMENT OF FUTURE TECHNOLOGY TEACHERS' ARTISTIC-PROJECTIVE ABILITIES: FOREIGN EXPERIENCE
}

\begin{abstract}
The necessity to form and develop future technology teachers' creative abilities has been stressed in the article. The psychologic-pedagogical researches of the leading specialists from Europe, the USA and Japan in the field of creative work and creativity have been analyzed. The main problems of the creative artistic-projective abilities development have been determined based on the analysis and synthesis of foreign and native philosophic, pedagogical and psychological literature dedicated to characteristics of such notions as "creative work" and "creativity". Approaches and conceptions providing students - future technology teachers - with creative activities have been singled out. The gist of psychological mechanism for forming teachers' creative personality has been established and its basic features have been determined as a result of the world experience of the theory and methods of creative abilities development generalization. The main features are as follows: an independence and an inclination towards divergent behavior; flexibility of thinking and readiness for everything new; motivation for self-actualization; striving for self-expressing and ability to creative work; ability to find out how to set and solve the problems. It has been mentioned that the technology teachers' artistic-projective activity requires their creative abilities development, which, in their turn, are formed on the ground of well-developed general and special (art, projective, technological, pedagogical) potencies. Therefore, the effectiveness of the students' art-projective knowledge and skills forming depends upon the extent their general, special and creative abilities have been developed. That is why skillful and pedagogically correct organization of future technology teachers' artistic-projective activities will inevitably provide the higher qualitatively new level of their creative abilities and creativity.
\end{abstract}

Key words: creative abilities, students, future teachers, creative work, creativity, artistic-projective activity, development.

\section{INTRODUCTION}

The forming of future technology teachers' preparedness towards pupils' artisticcreative abilities development is a crucial part of their professional becoming in the up-todate living conditions. That is why the problem of artistic-projected training of students studying "Technological Education", which is to be based upon future teachers' creative activity, is becoming extremely topical.

Rather clear tasks should be outlined, the proper corresponding conditions should be provided, the creative educational-developing surroundings should be formed in order to find out the students' natural inclinations and to further develop them into artisticprojective activity. 


\section{THE AIM OF THE STUDY}

So, the analysis of foreign experience in discovering nature of creative inclinations and determining on its basis the gist and main ways of technology teachers' creative work and creativity development in the contemporary Ukrainian school make the aim of this article.

\section{THEORETICAL FRAMEWORK AND RESEARCH METHODS}

The statement about the creative essence of a personality, systematic approach to the educational process research, individual activity approach, the ideas of education humanization compose the theoretical-methodological basis of the research. This paper is based upon the philosophy of creativity, methodology of contemporary pedagogy, upbringing ideas of aesthetics, theoretical approaches to choosing professional education content.

The main methods used for achieving the aim set are: analysis and synthesis of the foreign and native philosophic, pedagogical and psychological literature dedicated to the characteristic of the notions "creative work", "creativity" as well as the peculiarities of a personality's creative inclinations development that have made it possible to discover the originality of this process in future technology teachers' artistic-projective training.

\section{RESULTS}

The notion "creative work" is closely connected with the notion "creativity" though they differ in terms of categories. Usually by "creative work" one means such an activity, which generates something new in its quality and that something is distinguished by its uniqueness but "creativity" is considered to be the potential, the inner human resource, the ability to refuse and to get rid of stereotypical means of thinking or the capacity to find out new variants of solving problems. Creativity may also be identified as the ability of a person to a constructive non-standard thinking and behaviour, recognition and development of one's personal experience.

We believe that an outstanding philosopher M. Berdyayev characterized the "creativity" in the most meaningful way while underlining that: 1) there is not any creativity without freedom of action; 2) the problem is the basis of creativity; 3) creativity means a vivid emotional feeling at a given moment; 4) creativity is connected with imagination, coming out beyond the boundaries of reality; 5) some inner doubts and contradictions are enclosed in the basis of creativity alongside with the search for truth and strenuous efforts on this way (Бердяев, 1994).

While talking about creative process one cannot but mention that a certain pragmatic element is its part and parcel, that is some primary understanding of the cause and reason together with the way of creativity and, in fact, the understanding of what exactly should be created.

It is worthwhile pointing out that it was only in the middle of the 20th century when the complex research on the creative work and creativity problems were thoroughly actualized. The representatives of psychoanalytic direction in psychology (E. Chris, L. Cuba and others) stated that creative work was the result of certain inner personal conflicts, and creativity was nothing but "regression which serves the Ego of a person" (Беликов, 2010).

The supporters of the so-called humanistic direction (O. Luk, A. Maslou, K. Rodgers, V. Satir, etc.) considered that creation (creative work) came into being, when there were no inner personal conflicts and a creative process served as a means of innate creative potential under the condition of removing the inner barriers and the outer obstacles. In connection with this context A. Maslou stressed that the necessity of self-expression was the most prevailing (Маслоу, 2003). K. Rodgers understood creativity as a person's ability to find out new means and ways of solving problems alongside with new means of self-expression. 
He thinks "a human being is not what he/she is but what he/she may become". The potential lies in people themselves (Роджерс, 2001).

The representatives of psychometric direction (G. Hilford, E. Torrens, et al.) consider that the individual's innate creative potential is genetically determined and therefore can be measured by standard tests. The term "creativity", as a special ability type was used for the first time in 1963 by G. Hilford (Hilford, 1950). According to E. Torrens creativity is "the ability to generate original ideas and use non-standard means of intellectual activities - in a broad sense; and divergent abilities - in a narrow sense. Creativity is a process of identifying and recognizing some lacks or gaps in information, a process of ideas and hypotheses initiation together with their verification and modification" (Torrens, 1988).

The approach of authors who distinguish four aspects in the creativity problem (Козленко, 1990) should be acknowledged as quite rightful: 1) creative process (H. Foster, H. Heyvin, A. Kropley, S. Mednik, R. Sternberg, T. Tardif, E. Torrens, K. Yung et al.); 2) creative product of creative personality's activity (F. Barron, D. Charrington, P. Jakson, S. Messik, V. Molyako, K. Teilor et al.); 3) a creative personality which performs a creative process (L. Binsvanger, E. De Bono, K. Kox, V. Me-Dugall, V. Rybalka, K. Rodgers, E. Rou et al.); 4) creative surroundings that form the need for creativity (R. Dilts, A. Maslou et al.).

While analyzing the creativity problem it should be stressed that the majority of psychologists in spite of all the existing distinctions in views treated creativity as an intellect aspect (E. DeBonoir, G. Hilford, E. Torrens, L. Termen, D. Vexler) and only later on began to consider it as a higher intellectual process ("superrationality" of creation by R. Mei, "dimensional thinks" by A. Rotenberg). A number of researchers (K. Kox, E. Rou, $\mathrm{K}$. Teilor et al.) concentrated their attentions upon studying the creative persons' motivational, communicative characteristics. S. Arieti made the attempt to study creativity as a peculiar synthesis of subconscious processes and logical thinking endowing and assuming a special term "tertiary process" to this synthesis. In contemporary researches the so-called synthetic approach in which the intellectual, personal and social driving forces are considered equally significant for the creativity development prevail (Бондарчук, 2010).

There exists quite a number of approaches among the psychology researchers concerning the creative abilities problem. Thus, D. Bohoyavlenska, A. Maslou, A. Oloh, A. Tannenbaum et al. consider that the creative abilities do not exist and the main role in creative behaviour determination and creative activity stimulation is played by a personality's intellect itself, motivations, values, qualities and virtues; H. Aizenk, K. Kox, L. Termen, D. Vexler et al. - the all prescribe creative abilities to intellect; G. Hilford, H. Gruber, Ya. Ponomaryev, K. Tailor et al. - they consider the creativity as an independent thinking quality, which does not correlate with intellect in its traditional understanding.

Thus, three directions in the psychologal researches on the creativity problem and creative inclinations can be traced: 1) cognitive (D. Bohoyavlenska, E. DeBono, G. Hilford, S. Mednik, R. Mei, M. Rorbah, A. Rotenberg, E. Torrens et al.); 2) personal (K. Kox, A. Maslou, Ya. Ponomaryev, K. Rodgers, E. Rou, K. Teilor et al.); 3) synthetic (K. Cheller, G. Feldheusen, S. Kaplan, F. Rashton, G. Renzulli, R. Sternberg, A. Tannenbaum et al.).

Within the limits of systemic approach a French mathematician G. Adamer determined four stages inherent to any creative process: 1) preparation (perceiving period of the problem, initial attempts to find out the solution); 2) incubation period (temporary stoppage of conscious work over the problem, shifting of its solving search to the subconscious level); 3) insight dawning at illumination (a sudden finding out the means of solving the problem which is accompanied by stormy positive emotions); 4) the 
development and approval of the result (verification of the received solution exactitude obtained by logical means, accomplishing the procedures of the problem practical solution, that means the idea implementation in the ultimate product, when knowledge, skills and inner resources play a decisive role).

The teacher plays a significant role in effective realization of these stages. In his scientific research an English scientist D. Oztsan substantiated and experimentally proved the significance of a teacher's professional position in students' creative development. The criteria of the teacher's work analysis were proclaimed: the students' dexterity to solve the tasks all by themselves and independently, to take the right and proper decisions, to be responsible for their decisions, to apply non-standard means while obtaining the ultimate product. He obtained the results which certified that the students' creative abilities development level is in direct dependence upon the teachers' creative abilities. The researcher also stated that the students' creativity development is influenced upon by those teachers who are doing some additional research over a certain theme or who are involved in an interesting project alongside with their main work. In D. Oztsan's view it is connected with the fact that while working and being engaged in different field people generate creative ideas more successfully (Oztsan, 2010).

Unfortunately, in spite of the accumulated research material on the creativity problem which had certain results in a theoretical and in a practical sense there does not exist any precise creativity theory up to now as well as there does not exist such notion of "creativity" that is equally acknowledged by everybody and also any qualitative methods which can diagnose this human ability to perform creative actions.

The researchers R. Finke, S. Smith, T. Vard et al. distinguish the following types of creativity: 1) a naïve creativity which is native to children because of their experience lack; 2) cultural creativity which lies in overcoming the experience, conscious aspiration to get rid of stereotypes of everyday consciousness and paragons of the common sense; 3 ) intellectual creativity, peculiar to scientists, inventors, manufacture rationalizers, etc.; 4) artistic creativity in different art fields; 5) entrepreneurial creativity, which reflects the need for creating new product, services or organizations people have the possession right; 6) communicative creativity, which is evident in collaboration with other people in the process of creative activity and capable both to motivate the creativity of others and to accumulate their creative experience (Smith, Vard, Finke, 1995).

The British psychologists K. Russel, F. Carter after having analyzed the scientific literature on creativity developed the enumeration of creativity characteristics stating definitely that a creative personality is capable of: 1) feeling the exquisite, unidentified, complex niceties and peculiarities of the surrounding world (sensitiveness to problem); 2) generating and producing a great number of various ideas (fluency and dexterity); 3) suggesting different kinds, types, categories of ideas (flexibility); 4) suggesting ideas, versions, additional details, means of solving problems (inventiveness); 5) expressing imagination, sense of humor and developing hypothetic possibilities (imagination, capability to structuralization); 6) demonstrating quite unexpected, original conduct useful for solving problems (originality, inventiveness and productivity); 7) refraining from adopting the typical, common suggestion, putting forward various ideas instead and selecting the best one of them (independent, nonstandardness); showing certitude of one's decision, in spite of proposition, idea, thought, which enable non-typical problem solution (confident, self-sufficient behavior style) (Роджерс, 2001).

Thus, the creativity, in the psychologists and teachers' research papers is presented as a person's integral capability, which can be and must be developed. However, the 
problem of forming creative inclinations and creativity though having received certain supports on a part from the world scientific community has not become yet, unfortunately, a very significant task for the majority of teachers.

The American scientists Yu. Pluker and R. Begeth, in particular, tried to substantiate the situation, peculiar to contemporary pedagogy, by forming a few myths about the creativity development problem, which do not allow teachers and psychologists to perceive it too seriously (Pluker, Beghetto, 2010). The researcher T. Lubart notes that the notion "creativity" carries in itself the idea of experimenting with new results which were obtained in the creating process: "Creativity is the ability to generate new results within the bounds of thematics and objects". These results must be new in the sense that they should go beyond the coping of what already exists" (Lubart, 1999). D. Leonard and V. Svep consider the creativity to be the process of forming and expressing new ideas that can be useful. Creativity is not a talent, therefore it cannot be regarded as a purposeful (goal seeking) process for organization of which a special approach is needed, the approach which allows to maximalize the individual endowments, experience and qualification (Leonard, Svep, 1999).

In his turn, G. Gelage mentions the multilateral character of creativity on which quite a number of social origin motive forces can produce an impact, in particular, such as culture or language (Gelage, 2002). M. Csikszentmihalyi suggests that creativity may be considered to be a form of social or cultural phenomenon but not only as a form of mental process (Csikszentmihalyi, 1999). Ch. Li and Ch. Kim consider that culture may cause the impact both on the creativity level and the means of incomprehension and measurement. Besides, they state that the creative conduct also depends upon individual driving forces ( $\mathrm{Li}, \mathrm{Kim}, 2010$ ).

There are some interesting research results in the field of creativity obtained by the scientists of Ibaracan University (Japan), who found out some cross-cultural distinctions in imaginations about that phenomenon between American and Asian countries students. "While studying the creativity the American students demonstrate their advantage in flexibility (the ability to change, to work flexibly with different ideas), but the Asian countries students, however, surpass and excel them in the ideas improvement and complication" (Ogawa, Kuehn-Ebert, DeVito, 2001).

Rather a weighty experience of creativity development was accumulated by Polish teachers-scientists. In Poland a certain work dealing with the pupils' creative potential development was conducted as extramural one or only at the non-state educational institutions. Nowadays quite a number of experiments which foresee the attempts to include into the state schools educational curricula lessons and tutorials the content of which is directed upon the pupils' creative potential are being realized. Besides, the higher educational establishment (especially the Warsaw Academy of Professional Education) began a special teachers' training course, in which teachers themselves are to create their own educational curricula so that they help and promote the pupils' creative potential development. The creative teachers' training syllabus is directed upon the solution of such main problems as elaboration and working out of creative person's perception methods research, technologies of the creative imagination, individuality, intuition, various types of creative potential development, methods of the creative atmosphere making, etc. (Karwowski, Gralewski, Lebuda, Wiśniewska, 2007).

Since the article deals with the creative inclinations forming within the bound students' artistic projecting and designing teaching we will base ourselves on G. Hilford's creativity conception as a personality's universal cognitive creative capacity. Hypothetically he differentiated the abilities which characterize creativity: 1) semantic flexibility (the ability 
to show the main distinctive feature of any object and to suggest a new means of its use); 2) figurative and graphic adaptive flexibility (the ability to change the form of stimulus in such a way that one can see in it new signs or indications and opportunities of using); 3) semantic spontaneous flexibility (the ability to produce various ideas in a non-standard situation); 4) originality if not eccentricity (the ability to produce remoted associations, to give unusual answers); 5) curiosity (sensitivity towards the problems of surrounding world); 6) the ability to develop hypothesis, "irrelevancy" (logical independence of reaction from stimulus); 7) fantasticality and fantasticalness (complete isolation and even detachment of answer from realia although the logical link between stimulus and reaction remains). These abilities G. Hilford united together under the name of "a divergent thinking" which is expressed in case when the problem is only to be detected, revealed and then formulated and when there does not exist any way of solving it beforehand (in contrast to convergent thinking oriented upon the well-known way of problem solution long in advance) (Hilford, 1950).

Besides, G. Hilford substantiated six creativity parameters: 1) the ability to detect, reveal and to put forward the problem; 2) the ability to generate a great number of ideas which emerge in a certain span of time (fluency of thought); 3 ) originality as the ability to produce ideas different from generally excepted views and the ability to react to any irritants in a non-standard way; 4) flexibility as the ability to produce various ideas; 5) the ability to improve the object by adding new details; 6) the ability to solve problems, that means the ability to analysis and synthesis (Hilford, 1959).

\section{CONCLUSIONS}

The results of the research conducted give the opportunity to use the best foreign experience in future technology teachers' creativity and creative artistic-projective inclination development process.

The psychological and pedagogical research analysis has enabled us to differentiate such main creative personality's features: 1) an independence and an inclination towards divergent conduct (for creating certain individual behaviour principles and standards, which do not always coincide with commonly and generally accepted and are indispensible); 2) the flexibility of thinking, willingness and readiness for everything new (stereotypes prevent and hamper creative thinking; the ability to refuse the common view upon everyday things, the striving to consider the problem from non-standard point of view form the verified way of finding out innovative decisions and selections); 3) motivation of self-actualization (creativity is impossible without self-expression and an individual point of view as well as vision of solving problems); 4) the ability to detect, to put forward and to solve problems.

These general statements approach us to the conclusion, that future technology teachers' personal creativity requires from them creative inclinations which, in their turn, are formed upon the basis of the well-developed general and special (artistic, projective, technological, pedagogical, etc.) capacities and aptitudes. Therefore, the effectiveness of the students' artistic-projective knowledge and skills forming depends upon the measure and extent to which their common special and creative capacities have been developed. That is why skillful and pedagogically correct organization of future technology teachers' artistic-projective activities will inevitably provide the higher qualitatively new level of their creative abilities and creativity.

The research carried does not exhaust the problem mentioned. The further research may turn out to be very promising especially concerning a pedagogical model of future technology teachers' creative artistic-projective training. 


\section{REFERENCES}

1. Csikszentmihalyi, M. (1999). Implications of a Systems Perspective for the Study of Creativity. In: Sternberg, R. J. (Ed.), Handbook of Creativity. Cambridge : Cambridge University Press, pp. 313-335.

2. Gelage, G. A. (2002). Creativity Style, Personality, and Artistic Endeavor. Genetic, Social, and General Psychology Monograph, No 128, pp. 213-234.

3. Hilford, G. P. (1950). Creativity. American Psychologist, No 5, pp. 444-454.

4. Hilford, G. P. (1959). Three Faces of Intellect. American Psychologist, No 14, pp. $469-479$.

5. Karwowski, M., Gralewski, J., Lebuda, I., Wiśniewska, E. (2007). Creative Teaching of Creativity Teachers: Polish Perspective. Thinking Skills and Creativity, No 2, pp. 57-61.

6. Li, Ch., Kim, Ch. (2010). Relationships Between Bilingualism and Adaptive Creative Style, Innovative Creative Style, and Creative Strengths among Korean American Students. Creativity Research Journal, Volume 22, Issue 4, pp. 402-407.

7. Leonard, D., Svep, W. (1999). When Sparks Fly: Igniting Creativity in Groups. Boston, Massachusetts : Harvard Business School Press, 242 p.

8. Lubart, T. (1999). Creativity across Cultures In: Sternberg, R. J. (Ed.), Handbook of Creativity. Cambridge University Press, pp. 339-350.

9. Ogawa, D., Kuehn-Ebert, C., DeVito, A. (2001). Differences in Creative Thinking between Japaneese and American Fifth-Grade Children. In: Ibaracan University Faculty of Education Bulletin, No 40, pp. 53-59.

10. Oztsan, D. (2010). Contributions of English Teachers' Behaviours on Students' Creative Thinking Abilities. Procedia Social and Behavioral Sciences, No 2, pp. 565-585.

11. Pluker, Yu., Beghetto, R. A. (2010). Why Creativity is Domain General, Why It Looks Domain Specific, and Why the Distinction does not Matter. In: Sternberg, R. J., Grigorenko, E. L., Singer, J. L. (Eds.), Who is creative? Washington, D.C. : American Psychological Association, pp. 153-167.

12. Smith, S. M., Vard, T. B., Finke, R. A. (1995). The Creative Cognition Approach. Retrieved 11.01.2016 from : http://bookfi.org/book/1366226-en.

13. Torrens, E. (1988). The Nature of Creativity as Manifest in the Testing. In : Sternberg, R., Tardif, T. (Eds.), The nature of Creativity. Cambridge : Cambridge. Press. pp. $43-75$.

14. Беликов, В. А. (2010). Образование. Деятельность. Личность [Education. Activity. Personality]. М. : Академия Естествознания, 310 p. (in Russian).

15. Бердяев, Н. А. (1994). Философия творчества, культуры и искусства: в 2-x m. (T. 1.) [Philosophy of Creation, Culture and Arts: in Two Volumes (Volume 1)]. М. : Искусство, 542 p. (in Russian).

16. Бондарчук, O. I. (2010). Креативність і когнітивне забезпечення особистісного розвитку керівників освітніх організацій [Creativity and Cognitive Ensuring of the Educational Institutions Leaders Personal Development]. Наука і освіта. Спец. вип.: проект «Когнітивні прочеси та творчість» [Science and Education. Special issue : the project "Cognitive Processes and Creativity"], pp. 4-7 (in Ukrainian).

17. Козленко, В. Н. (1990). Проблема креативности личности [Problem of Personality's Creativity]. Психология творчества [Psychology of Creativity], pp. 131-148 (in Russian). 
18. Маслоу, А. (2003). Мотивация и личность [Motivation and Personality]. СПб. : Питер, 325 p. (in Russian).

19. Рассел, К. (2003). Развивайте интеллект. Упражнения для развития творческого мышления, памяти, сообразительности и интеллекта [Develop Intellect. Exercises for the Creative Thinking, Memory, Quickness of Wit and Intellect Development]. М. : Астрель, 144 p. (in Russian).

20. Роджерс, К. (2001). Становление личности. Взгляд на психотерапию [Personality’s Becoming. Views upon Psychotherapy]. М. : ЭКСМО-Преcc, 416 p. (in Russian). 